\title{
Social stress in laboratory rats Rattus norvegicus results in decreased immune competence of the offspring
}

\author{
Alexander V. PRONIN, Tatyana N. NIKOLAEVA, Anna V. DEYEVA, \\ Ludmila G. ZAYTSEVA, Elena I. VASIL'EVA, Galina B. KIRILLICHEVA, \\ Irina G. BATURINA, Marina S. SOLOV'EVA and Vladimir M. ZAKHAROV
}

Pronin A. V., Nikolaeva T. N., Deyeva A. V., Zaytseva L. G., Vasil'eva E. I., Kirillicheva G. B., Baturina I. G., Solov'eva M. S. and Zakharov V. M. 1997. Social stress in laboratory rats Rattus norvegicus results in decreased immune competence of the offspring. [In: Developmental homeostasis in natural populations of mammals: phenetic approach. V. M. Zakharov and A. V. Yablokov, eds]. Acta Theriologica, Suppl. 4: $33-40$.

An immune system status of socially stressed laboratory rats Rattus norvegicus Berkenhout, 1769 and their offsprings was studied. Several tests on activity of the macrophages and lymphocytes as well as on the tumour necrosis factor a (TNFa) activity in the blood serum were used to assess an immune system status of the stressed and control groups of rats. The results indicated that social stress led to obvious alterations in the immune system of the stressed rats and especially of their offspring, where the changes were more pronounced.

N. F. Gamaleya Institute for Epidemiology and Microbiology, Russian Academy of Medical Sciences, Gamaleya Str. 18, Moscow 123098, Russia (AVP, TNN, AVD, LGZ, EIV, GBK, IGB, MSS); N. K. Koltzov Institute of Developmental Biology, Russian Academy of Sciences, Vavilov Str. 26, Moscow 117808, Russia (VMZ)

Key words: Rattus norvegicus, phagocytic cell, lymphocyte proliferation, social stress

\section{Introduction}

Consequences of the high density and social stress impact have been demonstrated in both natural populations studies and laboratory experiments (Tompson 1957, Christian and Davis 1964, Shilov 1977, Moshkin et al. 1990, Naumenko et al. 1990, Pratt and Lisk 1990, Zakharov et al. 1991). Changes in an organism's condition has been indicated by developmental stability decrease revealed for the progeny of socially stressed pregnant females of rat (Valetsky et al. 1997). However, it is also important to answer the question if these morphological alterations are accompanied by changes in an immune status, as one of the crucial parameters of an organism's condition and its viability.

To detect possible changes not only in stressed individuals, but also in their progeny, is essential to estimate the population consequence of the impact. The latter seems to be especially important, as it has been shown that viral infections 
at the pregnancy duration lead to more serious changes in immune status of the offsprings than in the infected mothers (Pronin et al. 1989, Kobets et al. 1995).

High lability of the immune system suppose a convenience of immunological tests to register any stress impact, including the social one. One of the early manifestation of stress is a discharge of granulocytes from the storages, a redistribution of lymphocytes followed by depletion of thymus and spleen (Ernström and Sandberg 1973, Cohen and Crnic 1985). Activity of the cells provided a natural resistance (natural killer cells, mononuclear cells) is also decreased under the stress influence (Plezity et al. 1987, Aguila et al. 1988). All these alterations finalised in a rise of the susceptibility to oncologic and infectious diseases (Lewis et al. 1983, Francois et al. 1987, Gotovceva et al. 1988). However, the data concerning the stress influence on immune competent cells proved to be not so definitive. Stress can be followed by activation of lymphoid cells (Sukhikh et al. 1983, Korneva and Schkhinek 1989), depression of neoplastic cell growth (De Chambre and Gosse 1973, Rabin and Salvin 1987), etc. The consequences of stress depend upon various parameters, including genetically controlled sensitivity to the stressor, an immune system status (Laudenslager et al. 1983, Lysle et al. 1989), etc. Activity of different cell subsets and different functions of a particular cell subset can be changed discordantly (Lysle et al. 1988). Therefore the crucial task is to make a right choice of the immunological tests allowing to predict the consequences of stress for the lymphoid organs and cells. Several tests on activity of the macrophages and lymphocytes as well as on the tumour necrosis factor a (TNFa) activity in the blood serum have been established as rather simple and effective system to assess the immune system status (Pronin et al. 1993, 1996).

The aim of the study was to test the selected immune parameters in rats exposed to the social stress as well as in their offsprings to detect possible changes in immune status under the stress impact.

\section{Material and methods}

Laboratory rats Rattus norvegicus Berkenhout, 1769 ("Bright") derived from the R. Trayon's strain "maze-Bright", selected according to their extrapolation ability revealed in the test with the complex labyrinth, were used in the study. Social stress was modelled by the maintenance of 2 pregnant females with 8 males in one cage. Each female in a control group was kept in a separate cage during 22 days of pregnancy (see Valetsky et al. 1997 and Borisov et al. 1997 for details of the experiment and strain description). Ten females from the control and 10 from the experimental groups (all 6 months old) were used for immunological study. Fourteen offsprings from the control group and 15 offsprings from the experimental group (all 1.5 months old) were tested.

The following parameters were included in the study to characterize the immune system status: (1) Bone marrow and thymus cell numbers were estimated according to the procedure described earlier (Pronin et al. 1996).

(2) Activity of different phagocyte enzymes, protein synthesis, tumour necrosis factor a (TNFa) production and phagocytosis were tested to assess the natural resistance (Zaytseva et al. 1988).

(3) Phagocytic activity of peritoneal macrophages was examined by ingestion of 14C-labeled Salmonella typhi vaccine. The level of protein synthesis was estimated by uptake of $14 \mathrm{C}$-labeled aminoacids through 
the standard procedure (Zaytseva et al. 1988). Results of these two tests were expressed as a count per minute $(\mathrm{cpm})$ for $1 \mathrm{ml}$ of the sample or for $1 \mathrm{mg}$ of the protein, respectively.

(4) Cathepsin D activity was determined by the Anson's test (Anson 1936). The activity of cathepsin D in macrophages and serum was expressed as a quantity of tyrosine (mg) produced by cathepsin D during an hour per $1 \mathrm{mg}$ of the protein.

(5) For determination of 5'-nucleotidase the non-organic phosphorus was measured in macrophages of the peritoneal exudate by the multiscan $\mathrm{MCC}$ at $630 \mathrm{~nm}$ wave length. The level of enzymatic activity for the control animals was considered to be $100 \%$ (Kirillicheva et al. 1988, Pronin et al. 1996).

(6) To estimate the level of the TNFa in serum we used the L929 target cells following the standard procedure (Le and Vilcek 1987, Pronin et al. 1996). Conventional units of activity were calculated by the serum dilution caused $50 \%$ lysis of the target cells.

(7) T-and B-cell proliferation induced by mitogens was estimated by 3 H-thymidine uptake into the DNA of cells incubated with mitogens. The radioactivity was measured at a scintillation b-spectrometer. The results were expressed as the cpm values (Pronin et al. 1989, 1996).

The arithmetical mean and standard error (SE) were calculated for each test under study, and $t$-statistics was used for the intersample comparison of the means (Sokal and Rohlf 1981).

\section{Results}

Some indications for an increase in number of bone marrow cells and a decrease in a thymus weight have been revealed under stress for both females and their progeny, that were more pronounced for the latter (Table 1). Among the parameters presented in Table 2 there is a slight tendency for a decrease in a cathepsin D activity in peritoneal macrophages under stress impact for females. In offsprings of stressed females the same tendency proved to be much more pronounced $(p<0.001)$. There was also significant decrease of phagocytosis in stressed offsprings as compared with the control ones $(p<0.05)$.

The tendency for a decrease in activities of 5'-nucleotidase and NaK-ATPase in stressed females, comparing with the control group, became highly significant for their progeny $(p<0.001)$ (Table 3$)$. Stress impact did not lead to an appearance of TNFa in the serum of females. TNFa in offsprings of the control rats was found in significant titres in 4 animals, while in offsprings of the stressed rats it was

Table 1. Bone marrow cellularity and thymus weight (mean $\pm \mathrm{SE}$ ) in different experimental groups of rats. ${ }^{*}$ significant $(p<0.05)$ difference between control and stressed group revealed by $t$-test.

\begin{tabular}{lccc}
\hline Groups & $n$ & $\begin{array}{c}\text { Cellularity of bone } \\
\text { marrow }\left(10^{6} / \text { femur }\right)\end{array}$ & $\begin{array}{c}\text { Thymus weight } \\
(\mathrm{mg})\end{array}$ \\
\hline Control & 3 & Mothers \\
Stressed & 3 & $70.0 \pm 24.7$ & $192.7 \pm 18.7$ \\
& & $71.1 \pm 8.7$ & $181.7 \pm 9.3$ \\
Control & 3 & Offsprings & \\
Stressed & 3 & $41.8 \pm 8.9$ & $175.3 \pm 26.6$ \\
\hline
\end{tabular}


Table 2. Functional activity of phagocytes (mean $\pm \mathrm{SE}$ ) in different groups of rats. ${ }^{*} p<0.05$, *** $p<0.001$ ( $t$-test).

\begin{tabular}{|c|c|c|c|c|c|c|}
\hline \multirow[b]{2}{*}{ Groups } & \multirow[b]{2}{*}{$n$} & \multirow{2}{*}{$\begin{array}{l}\text { Phagocy- } \\
\text { tosis }\end{array}$} & \multirow{2}{*}{$\begin{array}{l}\text { Protein } \\
\text { synthesis }\end{array}$} & \multicolumn{3}{|c|}{ Cathepsin D in: } \\
\hline & & & & $\begin{array}{c}\text { peritoneal } \\
\text { macrophages }\end{array}$ & $\begin{array}{l}\text { blood } \\
\text { cells }\end{array}$ & serum \\
\hline \multicolumn{7}{|c|}{ Adult } \\
\hline Control & 10 & $10.1 \pm 0.5$ & $167.1 \pm 22.8$ & $415.0 \pm 37.1$ & $198.0 \pm 25.6$ & $18.0 \pm 3.3$ \\
\hline Stressed & 8 & $11.1 \pm 1.6$ & $256.4 \pm 67.9$ & $337.0 \pm 22.7$ & $230.0 \pm 11.6$ & $15.7 \pm 1.9$ \\
\hline & \multicolumn{6}{|c|}{ Offspring } \\
\hline Control & 14 & $37.8 \pm 6.5$ & $243.6 \pm 36.1$ & $571.0 \pm 37.1$ & $153.0 \pm 17.8$ & $11.2 \pm 1.6$ \\
\hline Stressed & 15 & $19.1 \pm 2.0^{*}$ & $239.0 \pm 38.6$ & $348.0 \pm 37.4^{* * *}$ & $170.0 \pm 19.1$ & $13.0 \pm 2.7$ \\
\hline
\end{tabular}

Table 3. Determination of 5'-nucleotidase and NaK-ATPase activities (mean $\pm \mathrm{SE}$ ) in peritoneal macrophages in different groups of rats. ${ }^{* * *} p<0.001$ ( $t$-test).

\begin{tabular}{lccc}
\hline Groups & $n$ & $\begin{array}{c}\text { 5'-nucleotidase } \\
\text { activity (\%) }\end{array}$ & $\begin{array}{c}\text { NaK-ATPase } \\
\text { activity (\%) }\end{array}$ \\
\hline Control & 7 & $100.0 \pm 8.2$ & $100.0 \pm 6.7$ \\
Stressed & 10 & $96.7 \pm 2.2$ & $89.5 \pm 4.0$ \\
& & Odfspring & \\
Control & 7 & $100.0 \pm 8.2$ & $100.0 \pm 6.7$ \\
Stressed & 7 & $38.9 \pm 3.2^{* * *}$ & $50.3 \pm 2.9^{* * *}$ \\
\hline
\end{tabular}

Table 4. Proliferative activity of spleen cells (mean $\pm \mathrm{SE}$ ) in different groups of rats. ${ }^{*} p<0.05$, **** $p<0.001$ ( $t$-test)

\begin{tabular}{|c|c|c|c|c|}
\hline \multirow{2}{*}{ Groups } & \multirow{2}{*}{$n$} & \multicolumn{3}{|c|}{${ }^{3} \mathrm{H}$-thymidine uptake $(\mathrm{cpm})$ in cell cultures } \\
\hline & & without mitogens & with Con A & with LPS \\
\hline \multicolumn{5}{|c|}{ Adult } \\
\hline Control & 5 & $2336 \pm 310$ & $25875 \pm 925$ & $2308 \pm 155$ \\
\hline Stressed & 4 & $1346 \pm 110^{*}$ & $13737 \pm 186^{* * *}$ & $1286 \pm 59^{* * *}$ \\
\hline \multicolumn{5}{|c|}{ Offspring } \\
\hline Control & 5 & $1689 \pm 34$ & $11721 \pm 249$ & $2204 \pm 40$ \\
\hline Stressed & 5 & $1300 \pm 60^{* * *}$ & $8962 \pm 234^{* * *}$ & $1167 \pm 33^{* * *}$ \\
\hline
\end{tabular}


found only in 1 animal (the mean values of titres in conventional units for the control and experimental groups proved to be equal to $60.6 \pm 9.3$ and $10.0 \pm 10.0$ respectively, $p<0.01$ ).

The same tendency for a decrease in the spontaneous and induced lymphocyte proliferation can be seen in both stressed females and their offsprings as compared with the control groups (Table 4). The difference between the experimental and control groups proved to be statistically significant for all parameters studied.

\section{Discussion}

An increase in bone marrow cellularity and a decrease in thymus weight appeared to be a compensatory reaction directed to the enrichment of an immune competent cells pool. This increase of bone marrow cells number can be a result of their migration from thymus followed by its hypoplasia. The latter can be also a consequence of the lymphocyte mortality (Zimin 1983, Gordeyeva and Nikolaeva 1991). Some indications of the quantitative changes in an immune system characterized by an increase in a cellularity of bone marrow and hypoplasia of thymus more noticeable in the offsprings of stressed rats (Table 1) could be a manifestation of these processes.

Different results indicating the stimulatory and inhibitory effects of stress impact on macrophage functional activity have been observed in the earlier studies (Loose et al. 1984, Plezity et al. 1987). In our study the social stress followed by alterations in some parameters of the macrophage activity. The most noticeable changes were observed in the offsprings whose macrophage phagocytic activity and cathepsin D activity were sharply decreased. The analysis of TNFa activity confirmed this conclusion.

Disappearance of TNFa in offspring of stressed rats can be a result of the macrophage function depression. An adenisine, as the 5'-nucleotidase product, is considered to be as one of the main physiological regulators of the immunological functions (Kirillicheva et al. 1988). Stimulation of the immune system is commonly accompanied by a decrease of the 5'-nucleotidase activity. We revealed a significant decrease in the activity of this enzyme for the offsprings of the stressed rats only (Table 3).

T-cells proliferation induced by mitogens has been established as the most informative test for evaluation of stress (Broom and Johnson 1993). Various stress impact is commonly followed by a proliferation decrease (Monjan and Collector 1977, Hoffman-Goetz et al. 1986, Odio et al. 1986, Rabin and Salvin 1987, Cunnick et al. 1988). In our study the indications for a decrease of T-lymphocyte proliferation with ConA in the stressed animals and their progeny were found (Table 4). These findings proved to be in agreement with the data on the negative correlation of macrophage and T-cell activities (Biozzi et al. 1984).

It has been mentioned that T-cells could be more sensitive to stress than B cells (Korneva and Schkhinek 1989). However, there are some data showing that a noise can lead to a decrease of B-cell proliferation with LPS (Monjan and 
Collector 1977). It has been found that various stress impact could lead to a suppression of B-cell activity and to a decrease in number of the antibody forming cells (Gisler 1974, Boranic et al. 1984, Esterling and Rabin 1987, Keller et al. 1988, Kirillina et al. 1989). Our data also showed a tendency to decrease of B-cell activity in the stressed rats (Table 4).

Thus, several immunological parameters under study indicate a depression of the immune system under the stress impact as compared with the control group. The changes revealed prove to be much more pronounced in the offsprings than in the females stressed at the pregnancy duration. This result corresponds to the earlier suggestion that stress impact at the pregnancy duration could have more serious consequences on the immune status and viability of the progeny than of the stressed females (Pronin et al. 1989, Kobets et al. 1995). The results also support an importance of developmental stability decrease revealed for the progeny of socially stressed females (Valetsky et al. 1997) and demonstrate that stress impact could lead to serious changes in an organism's condition and population consequences, as it has been suggested in the earlier field studies (Zakharov et al. 1991).

Acknowledgements: We are grateful to the staff of the laboratory of postnatal ontogenesis in the Institute of Developmental Biology, Russian Academy of Sciences for the experimental material presented for the study and stimulating discussion of the results. We are very grateful to anonymous referees who provided very helpful comments and corrections of English.

\section{References}

Aguila H. N., Pakes S. P., Lai W. S. and Lu Y. S. 1988. The effect of transportation stress on splenic natural killer cell activity in C57Bl/6 mice. Laboratory Animal Sciences 38: 148-151.

Anson M. L. 1936. Estimation of cathepsin with haemoglobin and partial purification of cathepsin. Journal of General Physiology 20: 565.

Biozzi G., Mounton D., Stiffel C. and Bouthillier Y. 1984. A major role of macrophages in quantitative genetic regulation of immunoresponsiveness and antiinfectious immunity. Advances in Immunology 36: 189-234.

Boranic M., Peričić D., Poljac-Blaźi M. and Sverko V. 1984. Suppression of the immune response by drugs interfering with the metabolism of serotonin. Experientia 40: 1153-1155.

Borisov V. I., Valetsky A. V., Dmitrieva I. L., Krushinskaya N. L. and Zakharov V. M. 1997. Inbreeding and outbreeding impact on developmental stability of laboratory rat Rattus norvegicus. [In: Developmental homeostasis in natural populations of mammals: phenetic approach. V. M. Zakharov and A. V. Yablokov, eds]. Acta Theriologica, Suppl. 4: 67-72.

Broom D. M. and Johnson K. G. 1993. Stress and animal welfare. Chapman and Hall, London: 1-211.

Christian J. J. and Davis D. E. 1964. Endocrine, behavior, and population. Science 146: 1550-1560.

Cohen J. J. and Crnic L. S. 1985. Behaviour, stress, and lymphocyte recirculation. [In: Stress, immunity and ageing. E. L. Cooper, ed]. Marcel Dekker Inc., New York: 73-76.

Cunnick J. E., Lysle D. T., Armfield A. and Rabin B. S. 1988. Shock-induced modulation of lymphocyte responsiveness and natural killer activity: differential mechanisms of induction. Brain, Behaviour, and Immunity 2: 102-113.

De Chambre R. P. and Gosse C. 1973. Individual versus group caging of mice with grafted tumours. Cancer Researches 25: 140-144.

Ernström U. and Sandberg G. 1973. Effects of adrenergic a- and b-receptor stimulation on the release of lymphocytes and granulocytes from the spleen. Scandinavian Journal of Haematology 11: $275-286$. 
Esterling B. and Rabin B. S. 1987. Stress-induced alteration of T-lymphocyte subsets and humoral immunity in mice. Behaviour Neurosciences 101: 115-119.

Francois M. H., Viza D., Roubertoux P. and Phillips J. 1987. Stress induced by aggression modifies the mortality and the immune response to herpes virus (HSVI) challenge in BALB/c mice. Journal of Neuroimmunology 16: 57-61.

Gisler R. H. 1974. Stress and hormonal regulation of the immune response in mice. Psychotherapy and Psychosomatic 23: 197-208.

Gordeyeva M. S. and Nikolaeva T. N. 1991. Immune morphological study of lymphoid organs in experimental inoculation of virulent and vaccine strains of Flexneri 2 shigellas. Zhurnal Microbiologii 6: 75-80. [In Russian with English summary]

Gotovceva E. P., Lavrukhina L. A., Babayanz A. A. and Ershov F. I. 1988. Preventive effect of INF during combined action of stress and experimental influenza infection. Voprosy Virusologii 33: 748-750. [In Russian with English summary]

Hoffman-Goetz L., Keir R., Thorne R., Houston M. E. and Young C. 1986. Chronic exercise stress in mice depressed splenic T lymphocyte mitogenesis in vitro. Clinical and Experimental Immunology 66: 551-557.

Keller S. E., Schleifep S. J., Liotta A. S. and Stein M. 1988. Stress-induced alterations of immunity in hypophysectomised rats. Proceeding of National Academy of Sciences USA 85: 9297-9301.

Kirillicheva G. B., Kirillichev A. A. and Tumanjan N. A. 1988. Behaviour of macrophage membrane enzymes after action of bacterial polysaccharide. [In: Immunemodulators in infectious pathology. S. V. Prozorovsky, ed]. N. F. Gamaleya Institute for Epidemiology and Microbiology Press, Moscow: 55-62. [In Russian]

Kirillina E. A., Zakharova L. A., Vasilenko A. M. and Mikhaylova A. A. 1989. Influence of myelopid on early manifestations of immune depressive effect of stress. Immunologiya 1: 41-43. [In Russian with English summary]

Kobets N. V., Chernyakhovskaya Y. U. and Fontalin L. N. 1995. Peculiarities of virus specific immune response in mice with congenitally acquired influenza infection. Folia Biologica 41: 295-303.

Korneva E. A. and Schkhinek Ye. K. 1989. Stress and immune system function. Uspekhi Phisiologicheskikh Nauk 20 (3): 3-20. [In Russian with English summary]

Laudenslager M. L., Ryan S. M., Drugan R. C., Hyson R. L. and Maier S. F. 1983. Coping and immunosuppression: Inescapable but not escapable shock suppresses lymphocyte proliferation. Science 221: 568-570.

Le J. and Vilcek J. 1987. Tumour necrosis factor and interleukin. 1. Cytokines with multiple overlapping biological activities. Laboratory Investigations 56: 234-248.

Lewis J. W., Shavit Y., Terman G. W., Nelson L. R., Gale R. P. and Liebeskind J. C. 1983. Apparent involvement of opioid peptides in stress-induced enhancement of tumour growth. Peptides 4: 635-638.

Loose L. D., Megirian R. and Turinsky J. 1984. Biochemical and functional alterations in macrophages after thermal injury. Infection and Immunity 44: 554-558.

Lysle D. T., Cunnick J. E., Caggiula A. R., Wood P. G. and Rabin B. S. 1988. 2-Deoxy-D-glucose modulation of T-lymphocyte reactivity: Differential effects on lymphoid compartments. Brain, Behaviour and Immunity 2: 212-221.

Lysle D. T., Cunnick J. E. and Rabin B. S. 1989. Stress-induced alterations of immunity in rodents. Reviews in Immunology 7: 28-53.

Monjan A. A. and Collector M. I. 1977. Stress-induced modulation of the immune response. Science 197: 307-308.

Moshkin M. P., Gerlinskaya L. A. and Evsikov V. I. 1990. [Stress reactiveness and its adaptive role in population cycles of mammals.] [In: Ontogenetic and evolution-genetic aspects of neuroendocrinal regulation of stress. E. V. Naumenko, ed]. Nauka, Novosibirsk: 171-180. [In Russian]

Naumenko E. V., Dygalo N. N. and Maslova L. N. 1990. [Permanent modification of stress reactiveness caused by stressors in prenatal ontogeny.] [In: Ontogenetic and evolution-genetic aspects of neuroendocrinal regulation of stress. E. V. Naumenko, ed]. Nauka, Novosibirsk: 40-54. [In Russian] 
Odio M., Galiszek A., Brodish A. and Ricardo M. J. 1986. Impairment of immune function after cessation of long-term chronic stress. Immunological Letters 13: 25-31.

Plezity K. D., Davydova T. B., Fomina V. G., Sukhikh G. T., Askerov M. A. and Cha Khak Gu 1987. Immunecorrective action of vitamine A in stress. Bulleten Experimentalnoi Biologii i Mediciny 104: 609-611. [In Russian with English summary]

Pratt N. C. and Lisk R. D. 1990. Dexamethasone can prevent stress-related litter deficits in the golden hamster. Behavioral and Neural Biology 54: 1-12.

Pronin A. V., Deeva A. V., Isaeva E. I. and Vyazov S. O. 1993. Immunological approach. [In: Biotest: A new integrated biological approach for assessing the condition of natural environments. V. M. Zakharov and G. M. Clarke, eds]. Moscow Affiliate of the International Biotest Foundation, Moscow: 56-59.

Pronin A. V., Deeva A. V., Nikolaeva T. N., Zaytseva L. G., Kirillicheva G. B., Baturina L. G. and Solov'eva M. S. 1996. Assessment of functional activity of immune system. [In: Consequences of the Chernobyl catastrophe: environmental health. V. M. Zakharov and E. Yu. Krysanov, eds]. Center for Russian Environmental Policy, Moscow Affiliate of International Biotest Foundation, Moscow: 86-95.

Pronin A. V., Mirchink E. P., Zuev V. A. and Deeva A. V. 1989. Suppressers of interleykin-1, which do not affect on the interleykin-2 production in infected mice. Immunologia 1: 29-32 [In Russian with English summary]

Rabin B. S. and Salvin S. B. 1987. Effect of differential housing and time on immune reactivity to sheep erythrocytes and Candida. Brain, Behaviour and Immunity 1: 267-275.

Shilov I. A. 1977. [Ecophisiological base of population interaction of animals.] Moscow University Press, Moskva: 3-261. [In Russian]

Sokal R. R. and Rohlf F. J. 1981. Biometry. Freeman, San Francisco: 1-859.

Sukhikh G. T., Meerson F. Z., Vanjko L. V. and Fuks B. B. 1983. Analysis of natural killer cell activity decrease after stress of immobilization. Vestnik AMN 11: 16-20. [In Russian with English summaryl

Thompson W. R. 1957. Influence of prenatal maternal anxiety on emotionality in young rats. Science 125: 698-699.

Valetsky A. V., Dmitrieva I. L., Krushinskaya N. L. and Zakharov V. M. 1997. Social stress impact on developmental stability of laboratory rat Rattus norvegicus. [In: Developmental homeostasis in natural populations of mammals: phenetic approach. V. M. Zakharov and A. V. Yablokov, eds]. Acta Theriologica, Suppl. 4: 27-32.

Zakharov V. M., Pankakoski E., Sheftel B. I., Peltonen A. and Hanski I. 1991. Developmental stability and population dynamics in the common shrew, Sorex araneus. American Naturalist 138: 797-810.

Zaytseva L. G., Vasilyeva E. I. and Tumanjan M. A. 1988. [Heterogeneity of macrophage population induced by inoculation of different agents.] [In: Immunemodulators in infectious pathology. S. V. Prozorovsky, ed]. N. F. Gamaleya Institute for Epidemiology and Microbiology Press, Moscow: 38-48. [In Russian]

Zimin Yu. I. 1983. [Stress: immunological aspects.] [In: Itogi Nauki i Tekhniki. Immunologiya. G. I. Marchuk and R. V. Petrov, eds]. VINITI, Moscow: 41-62. [In Russian]

Received 7 December 1995, revised 28 May 1997, accepted 10 June 1997. 